\title{
Assessing Strategic Management Accounting Practices in Public Interest Companies in Malaysia
}

\section{Nik Herda Nik Abdullah*}

Taylor's Business School, Taylor's University, Malaysia

* nikherda.nikabdullah@ taylors.edu.my

\begin{tabular}{l}
\hline Article Info \\
\hline Received : 2020-01-08 \\
Accepted : $2020-01-09$ \\
Published : 2020-01-28
\end{tabular}

Key words: public interest companies; government-linked companies; strategic management accounting; management accounting

\begin{abstract}
Strategic management accounting (SMA) practices play important roles in supporting decision making and strategic plan positioning in a firm. SMA practices comprise a range of useful and relevant techniques to facilitate a firm's value. Through these techniques, a firm would be able to achieve competitive advantage and sustain economic growth, which leads to long-term performance. Recently, the role of SMA techniques in enhancing business performance has become the focus of many studies, unfortunately, studies that accessing the adoption of SMA practices in organizations particularly in Malaysia are not widely available. Hence, the purpose of this paper is to investigate the extent of SMA practices in public interest companies in Malaysia called Government Linked Companies (GLCs). Through SPSS analysis of data collected from 215 questionnaires, the study shows that top management of GLCs has a better understanding of SMA practices due to extensive use of SMA techniques which discovered from the findings and believe that it can benefit their organization. This paper has enriched the literature and provided an assessment of SMA practices for researchers and practitioners which can improve competitiveness in the industry, business prosperity, and secure long-term performance.
\end{abstract}

\section{Introduction}

Strategic management accounting (SMA) is argued to be one of the accounting practices needed to create value (Abdullah and Said, 2016). Although SMA practices are widely embraced by many countries, such as Australia and Europe; but in the local context, the practices of SMA not broadly adopted. A study by Sulaiman et al. (2004) concluded that there are many firms that still adopt conventional management accounting techniques, this condition occurs due to lack of awareness, expertise, and top management support. While Yap et al. (2013) found that the adoption rates for SMA practices by Malaysian companies were comparatively lower than in other countries. However, in manufacturing industries such as Electrical and Electronics companies, it is found that certain SMA techniques are widely used (Nordin et al., 2009). Due to this uncertainty level of SMA usage in Malaysia context, it is important to discover the extent of SMA practices among Malaysia public interest companies which are known as Government Linked Companies (GLCs).

GLCs contributed extensively towards the development of economic growth of the nation by improving the quality of life for Malaysians society such as a large scale of infrastructure (Abdullah, 2019; Abdullah and Said, 2016; Ahmad et al., 2017). Thus, this study emphasized on SMA practices in GLCs due to the importance of having it in every GLCs as it reflects on longterm performance, business sustainability and environmentally with competitive advantages. The specific focus should give to GLCs due to its uniqueness. Indeed, GLCs are unique from other entities with their government ownerships. Thus, GLCs are not only significant for the Malaysian economy but also sustain its long-term performance, they will be able to continuously create value for its shareholders through dividend pay-out that effects on the total shareholder's return.

Hence, the objective of this study is to investigate the extent of SMA techniques in GLCs that will create a superior performance of the companies. This paper is organized as follows. 
Section 2 describes the related literature on SMA practices and GLCs. Section 3 introduces the methodology used throughout this paper. Sections 4 to describe the findings and discussions. Finally, Section 5 presents the conclusion, limitation, and future research.

\section{Literature Review}

\section{Strategic management accounting}

Many authors consider SMA as the adoption of methods, systems or techniques, referred to as "practices". The list of practices forms the basis for most empirical research intending to measure the spread of SMA in businesses. It also forms the core of the teaching content that refers to SMA. This section seeks to discover which practices the authors associate with SMA, and what they cover. Table 1 has been established drawing on four empirical studies that are often cited in the literature: Guilding et al. (2000), Cravens and Guilding (2001), Cadez and Guilding (2008), and Cinquini and Tenucci (2010). To clarify, the major methods are grouped together as far as possible, building on the classifications drawn up by the authors of these studies, although they do not all use exactly the same typology. Consequently, based on this method, the number of crosses (from one to four) corresponds to the number of studies (Malleret et al, 2015).

Based on the four empirical studies that are often cited in the literature, this study adopted the SMA techniques studied by Cadez and Guilding (2008). The selection of SMA techniques identified by Cadez and Guilding is because the study had introduced the most comprehensive set of SMA techniques as compared to other most cited studies shown in Table 1. Thus, this study is often cited by past and recent studies such as Soheilirad and Sofian (2016), Turner et al. (2017), Arunruangsirilert and Chonglerttham (2017), Kalkhouran et al. (2017). Therefore, this study has adopted a study by Cadez and Guilding (2008), which extracted 16 SMA techniques that were classified into five categories namely planning, control and performance measurements, strategic decision-making, competitor accounting, and customer accounting.

Thus, Table 1 provides an overview of the four empirical studies that are often cited in the SMA literature, which can be concluded that the study by Cadez and Guilding (2008) has a most extensive list of techniques in SMA. Besides, this table is also providing justification for why this current study adopted the 16 SMA techniques established by Cadez and Guilding. The next subsection presents the definitions of the sixteen (16) SMA techniques employed in this study.

Table 1: SMA Practices (Source: Malleret, Villarmois and Levant, 2015)

\begin{tabular}{|c|c|c|c|c|}
\hline $7^{\text {Reference }}$ & $\begin{array}{l}\text { Guilding et al. } \\
\qquad(2000)\end{array}$ & $\begin{array}{c}\text { Cravens and } \\
\text { Guilding (2001) }\end{array}$ & $\begin{array}{c}\text { Cadez and } \\
\text { Guilding (2008) }\end{array}$ & $\begin{array}{c}\text { Cinquini and } \\
\text { Tenucci (2010) }\end{array}$ \\
\hline \multicolumn{5}{|l|}{ Method } \\
\hline $\mathrm{ABC} / \mathrm{M}$ & & $\mathrm{XX}$ & & $\mathrm{XX}$ \\
\hline Attribute costing & XXX & XXX & XXX & \\
\hline Lean accounting & & & & $?^{\text {iv }}$ \\
\hline Life cycle costing & XXXX & XXXX & XXXX & $\mathrm{XXXX}+\mathrm{TCO}^{\mathrm{v}}$ \\
\hline Quality costing & $\mathrm{XXXX}$ & $\mathrm{XXXX}$ & $\mathrm{XXXX}$ & $\mathrm{XXXX}$ \\
\hline Target costing & XXXX & XXXX & XXXX & XXXX \\
\hline Value chain costing & $\mathrm{XXXX}$ & XXXX & $\mathrm{XXXX}$ & $\mathrm{XXXX}$ \\
\hline Strategic costing & $\mathrm{XXX}$ & $\mathrm{XXX}$ & $\mathrm{XXX}$ & \\
\hline Strategic pricing & XXX & XXX & XXX & \\
\hline Brand valuation $^{\text {vi }}$ & XXX & XXX & XXX & \\
\hline $\begin{array}{l}\text { Customer profitability } \\
\text { analysis }\end{array}$ & & & $X X$ & \\
\hline $\begin{array}{l}\text { Lifetime customer } \\
\text { profitability analysis }\end{array}$ & & & $\mathrm{X}$ & $\mathrm{XX}$ \\
\hline $\begin{array}{l}\text { Valuation of customers } \\
\text { as assets }\end{array}$ & & & $\mathrm{X}$ & \\
\hline \multirow{3}{*}{$\begin{array}{l}\text { Competitive position } \\
\text { monitoring } \\
\text { Competitor cost } \\
\text { assessment }\end{array}$} & XXXX & $\mathrm{XXXX}$ & $\mathrm{XXXX}$ & $\mathrm{XXXX}$ \\
\hline & $\mathrm{XXXX}$ & $\mathrm{XXXX}$ & $\mathrm{XXXX}$ & $\mathrm{XXXX}$ \\
\hline & XXXX & XXXX & XXXX & XXX \\
\hline
\end{tabular}




\begin{tabular}{|c|c|c|c|c|}
\hline Method & $\begin{array}{l}\text { Guilding et al. } \\
\qquad(2000)\end{array}$ & $\begin{array}{c}\text { Cravens and } \\
\text { Guilding (2001) }\end{array}$ & $\begin{array}{c}\text { Cadez and } \\
\text { Guilding (2008) }\end{array}$ & $\begin{array}{c}\text { Cinquini and } \\
\text { Tenucci (2010) }\end{array}$ \\
\hline \multicolumn{5}{|l|}{$\begin{array}{l}\text { Competitor performance } \\
\text { based on public } \\
\text { financial statement }\end{array}$} \\
\hline $\begin{array}{l}\text { Benchmarking } \\
\text { Integrated performance } \\
\text { measurement and } \\
\text { Balance Scorecard }\end{array}$ & & $\begin{array}{l}\mathrm{XXX} \\
\mathrm{XXX}\end{array}$ & $\begin{array}{l}\mathrm{XXX} \\
\mathrm{XXX}\end{array}$ & $\begin{array}{l}\mathrm{XXX} \\
\mathrm{XXX}\end{array}$ \\
\hline $\begin{array}{l}\text { Choice criteria named } \\
\text { by authors }\end{array}$ & $\begin{array}{l}\text { "extent to which } \\
\text { a management } \\
\text { accounting } \\
\text { practice } \\
\text { embodies } \\
\text { strategic } \\
\text { orientation" } \\
\text { (p.117) }\end{array}$ & $\begin{array}{l}\text { "Practices } \\
\text { highlighting an } \\
\text { external and } \\
\text { future focus" } \\
\text { (p.100) }\end{array}$ & $\begin{array}{c}\text { "Environmental } \\
\text { (outward-looking) } \\
\text { and/or long-term } \\
\text { (forward-looking)" } \\
\text { (p.836) }\end{array}$ & $\begin{array}{c}\text { "External/future } \\
\text { focus, } \\
\text { multidimensionality } \\
\text { (objects) and } \\
\text { measurement } \\
\text { typologies (financial } \\
\text { vs non-financial)" (p. } \\
232 \text { ) } \\
\end{array}$ \\
\hline Total & $12(11)$ & $15(14)$ & 16 & 11 \\
\hline Number of groups & $\begin{array}{l}\text { No group } \\
\text { ex ante }\end{array}$ & 4 & 5 & 4 \\
\hline
\end{tabular}

Notes from Malleret et al. (2015)

iv Cinquini and Tenucci only mention Lean Accounting to say that they will not select it. No other study includes this technique, but it may be present in firms under other names.

v Total Cost of Ownership and Life Cycle Costing have been merged since both methods have similar purposes.

vi Only one line is devoted to brand management, even though the authors break it down into Brand Value Budgeting and Brand Value Monitoring.

\section{Costing}

Superior strategies, which are based on strategic and marketing information, can be developed and identified by organizations to provide a sustainable competitive advantage with costing data (Cadez and Guilding, 2008). Based on trends found in past studies, the conceptualization of costing comprised of five major techniques. These techniques are life-cycle costing, attribute costing, quality costing, value chain costing and target costing.

Attribute costing is a technique provides the costing of specific product attributes to customers. Products are comprised of a set of attributes, which made out of commodities that attract consumers. These attributes include reliability and warranty arrangements, the degree of finish and trim, operating performance variables, and service factors, distinguish products and match product attributes according to consumers' preferences to ensure a firm's market share (Guilding et al., 2000).

The life-cycle costing has been discussed in various work including De Menna et al. (2018), and Cescon et al. (2019). This technique is an appraisal of costs based on the length of stages of a product or service's life. It explained the strategic effects linked to this point of view by claiming the relevant timeframe in life cycle costing is influenced by the stages in a product's life, rather than annual costs appraisals. These stages may include design, introduction, growth, maturity, decline, and eventually abandonment (Cadez and Guilding, 2008).

Quality costing consisted of those costs associated with the creation, identification, repair, and prevention of defects. These quality costs are classified as prevention, appraisal and failure costs (Cadez and Guilding, 2008; Heagy, 1991). This analysis provides information to management by highlighting quality problems of products or services, which can be a source of competitive advantage. Hence, these costs should be monitored so that the optimum level of relativities can be secured (Guilding et al., 2000).

Target costing is a method used during the process to design a product to fulfill customers' needs and the determination of a product's target cost (Guilding et al., 2000; Turner 
et al., 2017). It involves estimating a cost calculated by subtracting a required profit margin from an estimated price. In other words, target costing is a technique in which costing is transformed into a costing philosophy that is forward-looking from ascertaining the correct monitor. The embracing of target costing is highest for firms operating in a competitive and volatile environment to gain a competitive advantage (Becker and Gaivoronski, 2018; Tan and Jusoh, 2012).

Value chain costing is a costing approach, which is grounded on the value chain analysis by Porter (1985) and was posited by Shank (2007). Porter (1985) stipulated that the competitive advantage of a marketplace can be obtained from the provision of better customer value that is equal to the customer cost, customer value or incur a lower cost. Porter described the series of activities that occur through the process of product design and distribution as chains link, which became the foundation for value chain analysis. Therefore, value chain analysis focuses on ascertaining how customers' value can be improved and how firms can lower the cost in a section of the value chain that is relevant to the firm (Guilding et al., 2000). Consequently, value chain costing offers, first, a beneficial extension for traditional cost analysis, and the insights on how to make or buy and forward or backward integrated decision-making (Abdullah and Senan, 2019).

Thus, these costing techniques focus on costing analyses which useful for identified and develop strategies. The costing analyses include costing on specific product attributes to customers, assessing product cost based on the life stages of the product, identified cost related to producing, identification, repair and prevention of defects product, determination of estimation product cost, margin profit and price, and costs related to product design and distribution. The costing techniques are very important in every organization regardless of whether they provide service or product to customers as they need to identify and estimate their product cost from the beginning cost involved to produce until distribution to the marketplace. Besides, these techniques are also allowed the firm to formulate their strategies according to the costing information.

\section{Planning, Control, and Performance Measurement}

The category of planning, control, and performance measurement is found to be associated with a strategic process, stimulate innovativeness and performance management through its two techniques namely benchmarking and integrated performance measurement also known as Balanced Scorecard. This category is a very essential area for organizations that have drawn the attention in management accounting and controls studies (Berry et al., 2009). Benchmarking comprises of the planning, control and performance aspects of strategic management accounting in integrated performance conceptualization and measurement, as studied by Kaplan and Norton (1996).

Benchmarking is an SMA technique that involves identifying the best practices and comparing them with the organizations' performance (Guilding et al., 2000). Cadez and Guilding (2008), and Pradhan et al. (2018) advocated that this involves the identification of the best practices and making a comparison of the ideal standard of an organization's performance, in order to improve performance. They are varied typologies for benchmarking, but Pradhan et al. (2018) mentioned they commonly highlight the external strategic orientation towards competitors.

Integrated performance measurement (Balanced Scorecard) system refers to how both financial and non-financial measures are defined that related to internal and external perspectives in order to allow comprehensive and integrated performance management (Cinquini and Tenucci, 2010). Hence, Cadez and Guilding (2008) posited that this system primarily focuses on performance knowledge acquisition, which is grounded on customer requirements. This measure involves monitoring departments to identify the critical factors that can be used to guarantee customers' satisfaction, which contributes to the performance planning that is forward-looking orientation. 
Thus, this category focused on elements of planning, control and performance measures, which derived from the techniques of benchmarking and integrated performance measurement. Benchmarking technique assists the firm to identify the best practices that can be adopted by the firm and provide a comparison of internal processes to an ideal standard, which acts as a performance measurement to improve firm performance. With benchmarking, the firm will be able to plan and control its strategic process to ensure according to the ideal standard. Besides, integrated performance measurement comprises financial and non-financial measurement for use to measure firm performance. Thus, planning, control, and performance measurement have related to each other as the firm plans and execute its strategy, they will need to control or monitor it by using the performance measurement. Therefore, any strategic decision will be at its ideal standard.

\section{Strategic Decision Making}

The category of strategic decision-making allows a firm to improve its decision-making skills while creating and sustaining a competitive advantage by assisting in the strategy formulation process, pricing decision process and assessing the value of its brand. Thus, this category comprises strategic costing, strategic pricing, and brand valuation.

Strategic costing is also known as strategic cost management is a technique that uses of cost data based on strategic and marketing information to develop and identify superior strategies that will sustain a competitive advantage (Cadez and Guilding, 2008). Past studies posited that strategic costing efficiently supports the search for competitive advantage (Shank,2007). Hence, strategic issues must be explicitly taken into account in the cost analysis.

Strategic pricing is an analysis of strategic factors for the pricing decision process. Exploration of strategic pricing is a crucial aspect of strategic management accounting. In this light, competitively oriented analysis based on strategic pricing can help firms get a betterinformed pricing decision. Aspects like price elasticity, competitor price reaction, economies of scale and experience and projected market growth are primary factors that could be assessed (Cadez and Guilding, 2008; Guilding et al., 2000).

Brand valuation is an analysis of the use of brand value as a basis for managerial decisions on the allocation of resources to support and enhance brand position (Guilding et al., 2000). Brand valuation is a subject of considerable debate in the field of accounting. Based on the brand valuation perspective of management accounting, it is apparent that brand valuation as potential as a measure of marketing achievements in a strong branded company. The strategic impact of brand valuation includes the dependence on the valuation method used (Guilding et al., 2000). In this regard, Cadez and Guilding (2008) suggested that financial brand valuation and assessment of brand strength should comprise of factors like leadership, stability, market, internationality, trend, support, and protection combined with historical brand profits. Hence, brand valuation allows the firm to manage the value of brands that give an impact on long-term benefits, and the allocation of resources to most profitable brands (McManus and Guilding, 2008; McManus, 2013).

Thus, the strategic decision-making method would allow the firm to develop and identify strategy effectively, assist in pricing decision processes and decisions on the allocation of resources to the enhance brand value. This would benefit the firm for long-term performance and sustainability.

\section{Competitor Accounting}

Competitor accounting method focusses on external orientation activities to contribute to the firm's competitive advantages by providing information relates to competitor position in the market, evaluation, and appraisal on competitors and assessment on competitors' cost. As a result, these techniques are useful in seplanning, decision-making, and strategy monitoring (Cescon et al., 2019). Thus, competitors accounting consists of three techniques namely competitor position monitoring, competitor performance appraisal and competitor cost assessment. 
Competitive position monitoring is the analysis of competitor positions within the industry by assessing and monitoring trends in competitor sales, market share, volume, unit costs, and return on sales. Thus, the monitoring of competitor position is a more comprehensive approach for a competitor evaluation. Past studies posited that this process specifies competitor information. This information such as market share, volume and unit costs, and sales allow firms to evaluate their position by comparing with major competitors and, in return, formulate or control its strategy (Cinquini and Tenucci, 2010; Guilding et al., 2000).

Competitor performance appraisal is a numerical analysis of a competitor's published statements as part of an assessment of a competitor's key sources of competitive advantage. Cinquini and Tenucci (2010) mentioned that public financial statements can be a good source to get information on competitors' performance evaluation and appraisal. In this light, Moon and Bates mentioned that such information types can be the primary source of firms' competitive advantage, and it monitors the level of profits, sale trends, and movements of assets and liability. Consequently, strategic and significant insights can be derived through carefully analyzing the competitors' published statements.

Competitor cost assessment is a provision of regularly updated estimates of a competitor's costs based on, for example, appraisal of facilities, technology, and economies of scale. According to Guilding et al (2000), competitor cost assessment is widely investigated in SMA practice and this partially contributes to the increase in technologically advanced investments. Simmonds (1981) discussed how competitors' cost structure is the focus of competitor cost assessment. Therefore, with competitor accounting, firms are able to analyse their competitors and react based on their future goals, assumptions, capabilities, and their current position. Besides, it allows the firm to monitor the competitive position through extensive analysis of the competition.

\section{Customer Accounting}

Customers constitute a unit of accounting analysis (McManus and Guilding, 2008; McManus, 2013). Thus, customer accounting comprises of all practices designed to evaluate, sale, cost or profit, based on customers or customer segments. This approach is considered as an SMA technique, as it is widely related to relational marketing (Cinquini and Tenucci, 2010). In this regard, it involves the conceptualization of the valuation of customers as assets, analysis of customers' lifetime profitability and analysis of customer profitability analysis.

Customer profitability analysis (CPA) involves the calculation of profit derived from a particular customer (Cadez and Guilding, 2008; Kasemsap, 2018; McManus, 2013). Cadez and Guilding (2008) posited that the profit calculation is based on sales and costs traceable to a specific customer. CPA is also known as "customer account profitability". This technique allows evaluating the relationships with customers. Besides, it improves strategy development and decision-making related to product development.

Lifetime customer profitability analysis involves extending the time horizon for customer profitability analysis to include future years (McManus and Guilding, 2008). McManus (2013) and Cadez and Guilding (2008) claimed that this is one of the most essential elements of customer accounting in the SMA technique. Cadez and Guilding (2008) postulated that this comprises extending the time boundary by including the future for the analysis of customer profitability. This technique utilized all expected future revenue streams and costs that will incur in catering for specific customers.

The technique of valuation of the customer as assets provides a calculation of the customers' value to the firm (Cadez and Guilding, 2008). Such valuation can be done by calculating a specific's present and future values, including all future streams attributable to a particular customer and assumes an external and forward-looking orientation.

Thus, based on previous studies, Cadez and Guilding (2008) drew sixteen SMA techniques from previous works, and they classified these techniques into five broad categories 
where three categories embodying themes of management accounting discussed in management accounting literature. These categories are, 1) costing which comprises of attribute costing, 2) life-cycle costing, 3) quality costing, 4) target costing and, 5) value chain costing; planning, control, and performance measurements which include, benchmarking integrated and, performance measurement; strategic decision-making comprising of strategic costing, strategic pricing and, brand valuation; competitor accounting including competitor cost assessment, competitive position monitoring and, competitor performance appraisal; and finally, customers accounting including customer profitability analysis, lifetime customer profitability analysis and, valuation of customers as assets. The summarise the sixteen SMA techniques by Cadez and Guilding (2008), which adopted in this study as stated in Table 2 under section methodology.

\section{The Relevance of Strategic Management Accounting to Malaysian GLCs}

Prominent scholars of SMA posited that the weaknesses of conventional management accounting can be resolved through the introduction of SMA techniques and would assist the organizations in making a decision in various aspects (Kaplan and Norton, 1996; Shank, 2007; Simmonds, 1981). In the context of Malaysia, the adoption of SMA practices is still relatively low in comparison to European countries and Australia. Sulaiman et al (2004) claimed that many firms still practice the traditional technique of management accounting. This is due to the lack of awareness, support, and expertise from the top management.

A study by Yap et al (2013) mentioned that most firms face challenges in forms of middlelevel managers and subordinates' refusal to embrace the new practice. In the meantime, as shown by a study on Malaysian Electrical and Electronics (E\&E) companies by Nordin et al (2009) found that E\&E companies adopt the SMA information widely. It indicates the companies' attempt to extend their management accounting information to a more externally focused and strategic material. It was concluded by Said et al (2012) that the extensive use of SMA information leads to better customer service process performance among local government agencies in Malaysia. Thus, SMA techniques provide features of competitive advantages and sustainability, for example, improve the strategic position of a firm and reduce costs, improve manufacturing costs through life-cycle costing and identify target cost, price and profit through target costing.

In this light, it is apparent that SMA practices would improve value creation in a firm, however, there are still question remaining on how these techniques benefit GLCs. Consequently, Porter (1985) suggested the adoption of value chain analysis so that firms can improve their position by creating values for their customers and achieve competitive advantage. Besides value chain analysis, the adoption of strategic cost analysis would assist in identifying the value chain and competitors' cost drivers to have a better understanding of the comparative competitiveness. As a result, this information can be used to identify cost savings and it will guide GLCs to acquire a competitive advantage.

On the other hand, the cost incurred through a product's life starts from the initial design phase of the products and services, as well as all through its development, launch, productions, and sales as well as after the product has been withdrawn from the market. Cescon et al. (2019) explained that life cycle costing helps predict and accumulates the costs throughout a products' entire life cycle. Therefore, life cycle costing can be a way to improve manufacturing costs control in GLCs as it helps better product planning and design, from the initial stage to make sure cost reduction is conducted effectively so that competitive advantage can be obtained.

Meanwhile, other techniques such as target costing will enable GLCs to identify the target cost that they should achieve. This technique can be used to ascertain the target price of the product in the market, and to determine the margin for target profit and the differences between the margin and the target-selling price to obtain target cost (Guilding et al., 2000). Target costing can be observed in the highly competitive consumer durable sector. The adoption of target costing has a major advantage, as it will be deployed during a product's design and planning stage. Consequently, it will have a maximum impact on product cost. On the other hand, value 
Assessing Strategic Management Accounting Practices in Public Interest Companies in Malaysia

engineering techniques and teardown analysis are highly useful in the implementation of target costing.

Thus, it is expected that SMA practices would improve performance among GLCs through achieving competitive advantages. However, there is still a lack of empirical studies on the level of adoption of SMA practices, particularly in GLCs. Therefore, as mentioned in the earlier subsection, this study will be accessing the level of the adoption of SMA practices among GLCs.

\section{Methodology}

\section{Sample and data collection}

This study adopts a quantitative approach through cross-sectional testing to address its objective. In order to conduct this exploratory analysis, this study used a questionnaire as a survey instrument. The survey was mailed to 455 state and federal level GLCs in Malaysia. This study used the population as a sample to increase the response rate (Kadir et al., 2014).

The respondents include Chief Executive Officer (CEO), Chief Finance Officer (CFO) and Financial Controller (Spraakman et al., 2018). Those who hold this position are usually those who oversee organizational strategies and their decisions have a direct impact on all senior managers (Spraakman et al., 2018). The response rate for the study was 47\%, as there were 215 valid and complete questionnaires received from the GLC. This response rate is within the range of mail surveys in the same field of academic research (Chenhall et al., 2011).

\section{Measurement of variable}

This study adopted measures used by Cadez and Guilding (2008) as shown in Table 2, which comprise 16 techniques, which were itemized together with a Likert-type scale. This scale ranges from "1" (not being practiced at all), to "10" (to a great extent). This scale was chosen in measuring the variables as it is simple to administer, reduces forced choice among the targeted respondents, and avoids data bias (Awang, 2014). The measurement for each variable is shown in the following table. 
Table 2: Measurement of SMA practices

\begin{tabular}{ll}
\hline Categories & SMA Techniques \\
\hline Costing & Attribute costing \\
& Life-cycle costing \\
& Quality costing \\
& Target costing \\
& Value-chain costing \\
\hline Planning, control and performance & Benchmarking \\
Measurement & Integrated performance measurement \\
\hline Strategic decision-making & Strategic costing (strategic cost management) \\
& Strategic pricing \\
& Brand valuation \\
\hline Competitor accounting & Competitor cost assessment \\
& Competitive position monitoring \\
\hline Customer accounting & Competitor performance appraisal \\
& Customer profitability analysis \\
& Lifetime customer profitability analysis \\
\hline
\end{tabular}

\section{Finding and discussion}

The results in Table 3 show the descriptive statistics for every item measuring the SMA practices construct. This construct is measured using 16 items in a questionnaire using the interval scale from 1 (not being practice at all) to 10 (to a great extent) with the given item statement. The items were coded as 01 to 16 . The mean score for every item ranged between 7.46 and 8.26 , while the standard deviation of the score ranged between 1.360 and 1.816.

Based on Cadez and Guilding (2008), SMA comprises sixteen (16) techniques, which can be divided into five categories. The descriptive analysis found that the category under Planning, control, and performance measurement appeared as the most popular technique in Malaysian GLCs with overall mean 7.75 which equivalent to $77.5 \%$ of usage. Under this category, useful analyses of data for both financial and non-financial information for managerial decision-making were provided. Furthermore, the technique of 'integrated performance measurement' (item 07), which comprises a balanced scorecard, has been widely used with the mean score of 7.76 and this is followed by 'benchmarking' (06) with the mean score 7.74.

Table 3: Descriptive statistics of SMA techniques

\begin{tabular}{clccc}
\hline Item & \multicolumn{1}{c}{ Statement } & N & Mean & Std. Dev. \\
\hline & SMA_1 Costing & & $\mathbf{7 . 5 7}$ & $\mathbf{1 . 2 2 9}$ \\
01 & Attribute costing & 215 & 7.59 & 1.384 \\
03 & Life-cycle costing & 215 & 7.51 & 1.482 \\
04 & Target costing & 215 & 7.56 & 1.348 \\
05 & Value-chain/activity costing & 215 & 7.61 & 1.365 \\
& SMA_2 Planning, control and performance measurement & 215 & 7.55 & 1.452 \\
06 & Benchmarking & 215 & 7.74 & 1.277 \\
07 & Integrated performance measurement & 215 & 7.76 & 1.285 \\
& SMA_3 Strategic decision-making & & $\mathbf{7 . 6 4}$ & $\mathbf{1 . 1 0 2}$ \\
08 & Strategic costing & 215 & 7.61 & 1.266 \\
09 & Strategic pricing & 215 & 7.67 & 1.263 \\
10 & Brand valuation & 215 & 7.55 & 1.376 \\
& SMA_4 Competitor accounting & & $\mathbf{7 . 2 8}$ & $\mathbf{1 . 1 8 4}$ \\
11 & Competitor cost assessment & 215 & 7.26 & 1.285 \\
12 & Competitive position monitoring & 215 & 7.33 & 1.217 \\
13 & Competitor performance appraisal & 215 & 7.25 & 1.260 \\
& SMA_5 Customer accounting & & $\mathbf{7 . 2 8}$ & $\mathbf{1 . 1 9 0}$ \\
14 & Customer profitability analysis & 215 & 7.39 & 1.232
\end{tabular}


Assessing Strategic Management Accounting Practices in Public Interest Companies in Malaysia

\begin{tabular}{clccc}
\hline Item & \multicolumn{1}{c}{ Statement } & N & Mean & Std. Dev. \\
\hline 15 & Lifetime customer profitability analysis & 215 & 7.25 & 1.269 \\
16 & Valuation of customers as assets & 215 & 7.20 & 1.271 \\
\hline
\end{tabular}

Balanced Scorecard developed by Kaplan and Norton (1992) has become a key performance measurement system for corporate managers to drive their performance. This is consistent with the study by Md Zain and Sulaiman (2011), which stated that due to KPI, many GLCs have adopted management accounting tools and techniques such as Balanced Scorecard and benchmarking. However, the finding is inconsistent with prior studies, for example, Majid and Sulaiman (2008) posited that techniques such as a balanced scorecard are not widely used in Malaysia due to high cost, time-consuming, lack of top management support, lack of expertise and lack of awareness.

The second category of SMA techniques that are widely used by GLCs is Strategic decision making with overall mean 7.64 which equivalent to $76.4 \%$ of usage. It is found that Items 'strategic costing' (item 08), 'strategic pricing' (item 09) and 'brand valuation' (item 10) are the most helpful among the techniques and are the most widely used with the mean scores of 7.61, 7.67 and 7.55 respectively. These techniques require strategic data on competitors and the external environment for the pricing decision process. The selection of SMA techniques by Malaysian GLCs appears consistent with Ryan et al. (2002) that posited the most appropriate accounting techniques are dependent on the cost and benefits of the information.

The third category is under Costing, with an overall mean usage score of 7.57 or $75.7 \%$. The most popular technique in this category is 'target costing' (item 04) with a mean score of 7.61, followed by 'attribute costing' (item 01) with a mean score of 7.59. This is consistent with a study by Tan and Jusoh (2012) with the high mean score of target costing in this category and Rosli and Said (2014) found that certain SMA techniques such as attribute costing are highly used in Malaysian GLCs. However, it is inconsistent with Majid and Sulaiman (2008), who posited target costing less used in Malaysia. Meanwhile, 'life cycle costing' (item 02), 'quality costing' (item 03) and 'value chain costing' (item 05) registered the mean score of 7.51, 7.56 and 7.55 respectively.

This analysis of descriptive statistics also found that the categories of Competitor accounting and Customer accounting seem to be less used techniques to the Malaysian GLCs with lower means usage which are 7.28 or $72.8 \%$. The techniques of 'valuation of customers as assets' (item 16) and 'lifetime customer profitability analysis' (item 15) under group SMA_4 have shown lower mean usage of 7.20 and 7.25 respectively compared to 'customer profitability analysis' which has a slightly higher mean score of 7.39. This outcome is consistent with Tan and Jusoh (2012), which found that these two techniques were less used by firms. Sedevich-Fons (2018) stated that the technique of valuation of customers as assets requires the computation of the present value of all future profit flows attributable to a particular customer while lifetime analysis of customers is involved extending the time horizon for customer profitability analysis to include future years. Due to the requirement of the basic data from customer profitability analysis, these two techniques of customer accounting were found to be overlapped.

As stated by Simmonds (1981), SMA practices involved the provision of data on competitors and with competitiveness in the business market, where it is crucial to analyze the competitors' unit cost, market share, and unit costs. However, surprisingly, it was found that there is limited use of techniques under Competitor accounting. All of the three techniques under competitor accounting have the mean scores of below 7.40. The item of 'Competitor performance appraisal' (item 13) had the lowest mean score of 7.25 while 'Competitor cost assessment' (item 11) and 'Competitors position monitoring' (item 12) had the mean score of 7.26 and 7.33 respectively. Overall, the descriptive statistics analysis indicates the extensive use of SMA techniques in GLCs which is more than $70 \%$ of usage. As discussed, the results also discovered 
some consistencies and inconsistencies with prior researches on the intensity of SMA usage in Malaysia.

\section{Conclusion}

In agreement with the characteristics of SMA, which are outward-looking focused on the external business environment, and forward look that secure long-term performance and sustainability, which defined and maintained a firm's competitive advantage. The study discovered a common practice of these techniques demonstrate that in recent years, the corporate managers have overcome the lack of awareness and expertise with the support of top management.

Due to evolution in the business environment, management accounting techniques became insufficient in providing timely and accurate reports which are to address the needs of strategic decision making. Thus, advanced management accounting techniques such as SMA techniques are necessary to overcome this limitation. SMA practices provide the company with appropriate, accurate and reliable information on the critical success factors within and outside organizations for a long-term period through it emphasizing the use of financial and non-financial information which focused on internal and external business analyses such as information on its competitors, customers, and market environment. This information used to make strategic decision making which reflects the company's performance.

Furthermore, the adoption of SMA practices is highly related to improving financial aspects of GLC's long-term sustainability, social and survival environmental. In spite of the significant contributions and implications of this study in the SMA field of knowledge, it has the following limitations. These limitations are related to the research design used in this study, which creates opportunities for future research. Similar studies can be extended to different industries or countries. Therefore, future research is possible in terms of sample, measurement, and methodology.

\section{References}

Abdullah, N. H. N. (2019). Gaining competitive advantage through new product development capability in Malaysian Government Linked Companies, Indonesian Journal of Economics, Social, and Humanities, 1, 37-49.

Abdullah, N. H. N. \& Said, J. (2016). Value Creation and Government Linked Companies: Towards high level of accountability. Information, 19(8A), 3125-3130.

Abdullah, A. \& Senan, N. (2019). The complementary association between value chain analysis and target costing system to strengthen the competitiveness: An applied study on Saudi manufacturing companies in Al-Kharj. Management Science Letters, 9(10), 1543-1552.

Ahmad, W., Shah, N. S. B. \& Yusuf, N. H. M. (2017). The Capital Structure: GovernmentLinked and Non-Government-Linked Companies in the Trading and Services Industry in Malaysia. Jurnal Intelek, 12(1).

Arunruangsirilert, T. \& Chonglerttham, S. (2017). Effect of corporate governance characteristics on strategic management accounting in Thailand. Asian Review of Accounting, 25(1), 85-105.

Awang, Z. (2014). A handbook on SEM for academicians and practitioners: the step by step practical guides for the beginners. MPWS Rich Resources. Bandar Baru Bangi.

Becker, D. M. \& Gaivoronski, A. A. (2018). Optimisation approach to target costing under uncertainty with application to ICT-service. International Journal of Production Research, 56(5), 1904-1917.

Cadez, S. \& Guilding, C. (2008). An exploratory investigation of an integrated contingency model of strategic management accounting. Accounting, Organizations and Society, 33(7-8), 836-863. 
Assessing Strategic Management Accounting Practices in Public Interest Companies in Malaysia

Chenhall, R. H., Hall, M. \& Smith, D. (2010). Social capital and management control systems: A study of a non-government organization. Accounting, organizations and Society, 35(8), 737-756.

Cinquini, L. \& Tenucci, A. (2010). Strategic management accounting and business strategy: a loose coupling?. Journal of Accounting and Organizational Change, 6(2), 228-259.

Cravens, K. S. \& Guilding, C. (2001). Brand value accounting: an international comparison of perceived managerial implications. Journal of International Accounting, Auditing and Taxation, 10(2), 197-221.

De Menna, F., Dietershagen, J., Loubiere, M. \& Vittuari, M. (2018). Life cycle costing of food waste: A review of methodological approaches. Waste Management, 73, 1-13.

Dekker, H. \& Smidt, P. (2003). A survey of the adoption and use of target costing in Dutch firms. International Journal of Production Economics, 84, 293-305.

Guilding, C., Cravens, K.S. \& Tayes, M. (2000). An international comparison of strategic management accounting practices. Management Accounting Research, 11, 113-135.

Heagy, C. D. (1991). Determining optimal quality costs by considering cost of lost sales. Journal of Cost Management, 5(3), 64-72.

Kadir, M. R. A., Abidin, Z. Z., Ramli, A. R. \& Surbaini, K. N. (2014). Factors Influencing A Business Towards Zakat Payment In Malaysia. International Journal of Science Commerce and Humanities, 2(3), 147-156.

Kalkhouran, A. A. N, Nedaei, B. H. N. \& Rasid, S. Z. A. (2017). The indirect effect of strategic management accounting in the relationship between CEO characteristics and their networking activities, and company performance. Journal of Accounting and Organizational Change, In press

Kaplan, R. S. \& Norton, D.P. (1992) The Balanced Scorecard: Measures that Drive Performance. Harvard Business Review, (January-February), 71-79.

Kaplan, R. S. \& Norton, D. P. (1996). Linking the balanced scorecard to strategy. California management review, 39(1), 53-79.

Kasemsap, K. (2018). Customer lifetime value. In Encyclopedia of Information Science and Technology. Fourth Edition (pp. 1584-1593). IGI Global.

Majid, A.J. \& Sulaiman, M. (2008). Implementation of activity based costing in Malaysia: A case study of two companies. Asian Review of Accounting, 16(1), 39-55.

Malleret, V., de La Villarmois, O. \& Levant, Y. (2015). Revisiting 30 years of SMA literature: What can we say, think and do? Retrieved from https://papers.ssrn.com/sol3/papers.cfm?abstract_id=2561249

McManus, L. (2013). Customer accounting and marketing performance measures in the hotel industry: Evidence from Australia. International Journal of Hospitality Management, 33, $140-152$.

McManus, L. \& Guilding, C. (2008). Exploring the potential of customer accounting: a synthesis of the accounting and marketing literatures. Journal of Marketing Management, 24(7-8), 771-795.

Nordin, R., Zainuddin, Y. \& Tayles, M. (2009). Strategic management accounting information elements: Malaysian evidence. Asia-Pacific Management Accounting Journal, 4(1), 17-34. 
Pradhan, D., Swain, P. K. \& Dash, M. (2018). Effect of management accounting techniques on supply chain and firm performance: An empirical study. International Journal of Mechanical Engineering and Technology, 9(5), 1049-1057.

Porter, M. E. (1985). Competitive advantage: creating and sustaining superior performance. New York: Free Press.

Rosli, H. R. \& Said, J. (2014). Strategic management accounting (SMA) usage in Malaysian Government Linked Companies (GLCs), 3rd International Conference on Accounting, Business and Economics (ICABEC2014), 27-28 Aug, Malaysia.

Ryan, B., Scapens, R.W. \& Theobald, M. (2002). Research Method and Methodology in Finance and Accounting. (2nd ed.), Thomson, Padstow.

Sangwa, N. R. \& Sangwan, K. S. (2018). Development of an integrated performance measurement framework for lean organizations. Journal of Manufacturing Technology Management, 29(1), 41-84.

Sedevich-Fons, L. (2018). Linking strategic management accounting and quality management systems. Business Process Management Journal, 24(6), 1302-1320.

Shank, J. K. (2007). Strategic cost management: uprising, downsizing, and right (?) sizing, in Bhimani, A. (Ed). Contemporary Issues in Management Accounting, Oxford

Simmonds K. (1981). Strategic Management Accounting. In Management Accounting (UK), April, 26-29.

Soheilirad, S. \& Sofian, S. (2016). A proposed model of the mediating effect of strategic management accounting on the relationship between perceived environmental uncertainty and firm performance. International Journal of Research-Granthaalayah, 4(1), 231-239.

Spekman, R. E., Kamauff Jr, J. W. \& Myhr, N. (1998). An empirical investigation into supply chain management: a perspective on partnerships. Supply Chain Management: An International Journal, 3(2), 53-67.

Sulaiman, M., Ahmad, N. \& Alwi, N. (2004). Management Accounting Practices in Selected Asian Countries: A Review of the Literature. Managerial Auditing Journal, 9(4), 493-508.

Tan, A. L. \& Jusoh, R. (2012). Business Strategy, Strategic Role of Accountant, Strategic Management Accounting and Their Links To Firm Performance: an Exploratory Study of Manufacturing Companies in Malaysia. Asia-Pacific Management Accounting Journal, 7(1), 59-94.

Turner, M. J., Way, S. A., Hodari, D. \& Witteman, W. (2017). Hotel property performance: The role of strategic management accounting. International Journal of Hospitality Management, $63,33-43$.

Yap, K. H. A., Lee, T. H. \& Said, J. (2013). Adoption, Benefits and Challenges of Strategic Management Accounting Practices: Evidence from emerging market. Asia Pacific Management Accounting Journal, 8(2), 27-45.

Zin, N. M. \& Sulaiman, S. (2011). Government-linked Companies Blue Book (GLCs Blue Book) as a complement to Balanced Scorecard (BSC) in the Government-Linked Companies transformation program. International Conference on Business and Economics Research 2010, 1, 294-297. 